\title{
Pelas veredas da ironia: o homoerotismo em $O$ pecado de João Agonia e $O$ beijo no asfalto
}

\author{
Solange Santana ${ }^{1}$
}

\begin{abstract}
Resumo: Sob a perspectiva comparatista, analisamos os diferentes caminhos tomados por Nelson Rodrigues, dramaturgo brasileiro, e Bernardo Santareno, teatrólogo português, na abordagem do homoerotismo em $O$ beijo no asfalto e $O$ pecado de João Agonia, respectivamente. Com interesse em detectar as diferentes configurações do tema e da linguagem discursiva, pretende-se verificar como a ironia, além de estar inserida já na ousadia em se abordar a temática, está presente em seus textos dramáticos. Mesmo trazendo este aspecto, ou justamente por trazê-lo, as configurações homoeróticas masculinas presentes nos textos dramáticos apontam para o contexto sociocultural, para os resquícios do preconceito que o homoerotismo carrega e que, ao mesmo tempo, faz com que os indivíduos o neguem.
\end{abstract}

Palavras-chave: Bernardo Santareno. Nelson Rodrigues. Ironia. Homoerotismo.

\section{Introdução}

O que mantém uma sociedade unida, outorgando-lhe singularidade, diferenciando-a de outras sociedades em épocas diferentes pode ser definido como uma teia de significações imaginárias que permeiam, orientam e dirigem o todo social, definindo o que é certo ou errado, o normal e o anormal, o que deve ser rechaçado ou valorizado, o que é possível ou impossível socialmente. A literatura dramática, entre outras incumbências, cumpre o papel de retratar o mundo circundante e suas leis sociais, tanto quanto as trangressões humanas.

Ensina-nos Roland Barthes (1989) que a literatura "acredita sensato o desejo do impossível" e é este desejo que faz do retrato literário da realidade ora a afirmação ora a negação dos valores tanto das grandes instâncias do poder como o governo, a igreja e a sociedade, quanto das microesferas cotidianas e ordinárias. Ao abordar temas que permeiam a vida, dentre eles, a sexualidade humana, em suas variadas configurações, a literatura nos dá experiências várias, olhares que tentam abrir as portas dos quartos, que espiam pelas fechaduras, reforçando o pudor social com o corpo e o gozo, mas também demonstrando que o avesso e a transgressão dos interditos sempre estiveram lado a lado com as normas vigentes no mundo ficcional da arte literária.

\footnotetext{
${ }^{1}$ Mestre pelo Programa de Pós-Graduação em Literatura e Cultura da Universidade Federal da Bahia. Faz parte do Grupo "Estudo do texto teatral em Língua Portuguesa" e desenvolve pesquisa em perspectiva comparada sobre a dramaturgia de Nelson Rodrigues e Bernardo Santareno, sob a orientação do Prof. Dr. Márcio Ricardo Coelho Muniz. E-mail: professorasolange@ hotmail.com.
} 
Nesse campo, por si mesmo controverso, porque envolvem regras, modelos de conduta, desejos e a subjetividade da linguagem, a cena política da ironia se presentificará, antes de tudo, a partir do ponto de vista do escritor que intencionalmente escolhe aderir ou repelir o convencional. A natureza transideológica dessa estratégia, conforme Linda Hutcheon (2000), vem para apontar que ela pode tanto ser usada como arma de culturas dominantes para manter a subserviência, quanto como uma força que "surge de um reconhecimento de que o eu socialmente construído é arbitrário e demanda revisão de valores e convenções" (WALKER, apud HUTCHEON, 2000, p. 56). Entendemos ironia como recurso discursivo e literário que se configura como "modo de combate, [...] paixão negativa para deslocar e aniquilar uma representação dominante do mundo, uma paixão que é vista como especialmente crucial quando os discursos estabelecidos e dominantes mostram grande capacidade absorvedora" (HUTCHEON, 2000, p. 54). A presença dessa estratégia em obras literárias que tratam de temas considerados tabus ou polêmicos permite que as realidades sociais sejam reanalisadas, fragmentando as relações humanas e seus significados, desconstruindo-os muitas vezes para apresentar outras definições do mundo. Sabe-se que a literatura, como um dos elementos que representa a vida social, interage com o meio circundante na medida em que o recria e é impelida pela estrutura sociocultural.

No limite deste texto, trataremos de dois dramaturgos nossos contemporâneos que, a nosso ver, podem ser incluídos no leque de autores que abordam a sexualidade humana com uma ácida ironia, uma vez que apontam para a necessidade de revisão de valores e convenções sociais: o português Bernardo Santareno (1920-1980) e o brasileiro Nelson Rodrigues (1912-1980). E, no rol já muito longo de obras destes dois autores, escolhemos um texto teatral de cada: $O$ beijo no asfalto, de Rodrigues; e O pecado de João Agonia, de Santareno. O motivo da escolha, como se verá à frente, deve-se ao elemento comum nos dois textos: a problematização das relações homoeróticas masculinas. Acredita-se que é através da ironia, em sua função opositiva ou 'contradiscursiva', que os dramaturgos tentavam despertar o espírito crítico do leitor/espectador, obrigando-os a questionar os valores sociais vigentes, a procurar por si outras verdades, visto que seus textos dramáticos não propiciam respostas para os conflitos, mas, incansavelmente, provocam, polemizam e problematizam as relações humanas.

Com interesse em detectar as diferentes configurações do tema e da linguagem discursiva, pretende-se verificar, sob a perspectiva comparatista, como a ironia, além de estar inserida já na ousadia em se abordar a temática, acontece ainda por meio da interdiscursividade, mecanismo que participa da estruturação do discurso irônico rodriguiano 
e santareniano, instituindo a argumentação direta e indiretamente estruturada, o paradoxo argumentativo, o afrontamento de ideias e normas institucionais, instaurando, muitas vezes, a polêmica e o incômodo (BRAIT, 2008). Nesta perspectiva, pode-se perceber que as configurações homoeróticas masculinas presentes nos textos dramáticos de Rodrigues e Santareno apontam para o contexto sociocultural, para os resquícios do preconceito que o homoerotismo ${ }^{2}$ carrega e que, ao mesmo tempo, faz com que os indivíduos o neguem.

\section{O homoerotismo sob os signos do trágico e da ironia}

Com relação à presença do homoerotismo na dramaturgia, vê-se que as primeiras representações do amor entre homens são tomadas pela tragicidade, permeando a literatura grega com morte e dor. Com relação a esse aspecto, Adrián Melo esclarece:

Como um destino fundante, as primeiras imagens ocidentais sobre os homens que amam outros homens têm o signo do trágico. Todos os candidatos que disputam na mitologia grega a honra de ser o primeiro mortal masculino enamorado de outro homem morreram prematuramente. Tamiris perdeu a fala e os sentidos como castigo por amar Jacinto. O belo Jacinto morreu rápido, ainda com suas vestimentas, e com o corpo ungido de azeite enquanto jogava o disco com seu amante Apolo. Laio, o rei legendário de Tebas, se enamorou de Crisipo e o raptou, levando-a a sua cidade, [mas Crisipo, com medo da reação paterna, suicida-se]. Anos depois, Laio tornase vítima de seu próprio filho: Édipo (MELO, 2005, p. 11) (Livre tradução da autora $)^{3}$.

A filiação das obras rodriguiana e santareniana à tragédia, neste sentido, é muita clara, uma vez que tanto em $O$ pecado de João Agonia ${ }^{4}$ quanto em $O$ beijo no asfalto ${ }^{5}$ as

\footnotetext{
${ }^{2}$ Embora consciente de que, segundo os estudos queers, os termos "homossexualismo" ou "homossexualidade" encontram-se comprometidos com o contexto médico-legal, psicológico, sexológico e higienista de onde surgiram e que levaram à construção social do preconceito contra o sujeito homossexual (COSTA, 1992), utilizaremos, como equivalentes, "homossexualismo" e "homoerotismo", e seus derivados, por acreditarmos que aquele contexto foi, na atualidade, superado, e por constatarmos que o uso de ambos é recorrente em textos da crítica literária dedicada ao assunto.

3 “Como un destino fundante, las primeiras imágenes occidentales sobre los hombres que aman a otros hombres tienen el signo de lo trágico. Todos los candidatos que se disputan en la mitología griega el honor de ser el primer mortal masculino enamorado de outro muchacho perecieron prematuramente. Támiris perdió el habla y los sentidos como castigo por amar a Jacinto. El hermoso Jacinto murió ligero de ropas y con el cuerpo ungido de aceite mientras jugaba al disco con su amante Apolo. Layo, el rey legendário de Tebas, se enamoró de Crisipo y lo rapto llhevandoselo a su ciudad. Años después fue víctima de su próprio hijo: Édipo" (MELO, 2005, p. 11).

${ }^{4}$ O pecado de João Agonia foi escrito em 1961 e "encenado, pela primeira vez, em 1965, na cidade de Barcelona, Espanha" (REBELLO, 1987). Neste texto, a sexualidade, apesar de tema tabu na sociedade, é assunto central, e o "pecado" aludido no título refere-se à orientação sexual homoafetiva do protagonista, João Agonia, que será assassinado pelos homens de sua família para que a ordem se reestabeleça em sua comunidade. As ações dramáticas desenvolvem-se, conforme esclarece o dramaturgo na apresentação do texto, em qualquer lugarejo serrano e primitivo, em Portugal. O caráter "primitivo" e indeterminado do locus dramático, assim
} 
personagens arrastam consigo o signo do trágico, sucumbindo diante das forças sociais ou autonegando suas vontades. Neste sentido, o trágico se corporifica como o conflito entre dois polos fundamentais: o homem e o mundo objetivo que o cerca (BORNHEIM, 1975), do qual a personagem sempre sairá derrotada. Um traço fundamental de todo trágico - a unidade de salvação e aniquilamento - de que nos fala Peter Szondi (2004) perpassa os textos dramáticos santareniano e rodriguiano, contudo, “[...] não é no declínio do herói que se cumpre a tragicidade, mas no fato de o homem sucumbir no caminho que tomou justamente para fugir da ruína" (SZONDI, 2004, p. 89). Pode-se dizer, em tais casos, que se presentifica nos textos, também, o que poderíamos chamar de ironia trágica, pois há "uma realidade hostil a todos os valores das personagens, o que faz com que o malogro seja inevitável" (MUECKE, 1995, p. 71). Vejamos, assim, como as criaturas rodriguiana e santareniana encontram o aniquilamento, ou melhor, reencontram-se com a tragicidade.

João Agonia, Aprígio e Arandir são as personagens trágicas que vivem as experiências gays nos textos dramáticos que compõem nosso corpus. Sabe-se que a homossexualidade de Arandir é forjada, porém, o protagonista não deixa de sofrer as consequências por não sê-lo. No que tange ao seu final trágico, a personagem é assassinada, não porque seja homossexual, mas por ser o objeto oculto de desejo de seu sogro, o qual, no dia em que o lotação atropelou o rapaz, testemunhou o beijo no asfalto, impressionando-se com a atitude do genro. Ao começar a contar a história para a filha, enquanto o marido de Selminha encontrava-se na delegacia, ela, logo, se irrita: “- Uma coisa, papai. O senhor sabe que, desde o meu namoro, o senhor nunca chamou Arandir pelo nome? Sério! Duvido! Papai! O senhor dizia "seu namorado". Depois: "seu noivo". Agora é "seu marido" ou, então, “meu genro". Escuta, papai!” (RODRIGUES, 1993, p. 947-948). Meio desconcertado, Aprígio desconversa e, apesar de a filha desafiá-lo a dizer o nome "Arandir", isto não ocorre.

Logo, nos chama atenção o caráter inefável de seu sentimento, o que cria uma ponte entre este diálogo e os momentos históricos do advento do Cristianismo que definia a relação

como definido pelo autor, diz muito sobre seus propósitos futuros. O pecado de João Agonia reparte-se em três atos, desmembrados em cenas que nos permitem conhecer os valores vigentes e as personagens. Esse mundo santareniano, por sua vez, é composto por três famílias - Agonia, Giesta e Lamas. Da primeira, têm-se José e Rita, pais de João, Fernando e Teresa, além de seus tios Miguel e Carlos, e Rosa, a avó; já da segunda, os Giestas, surgem Toino e Maria, filhos de Guilhermina; da terceira, origina-se Manuel, ex colega de quartel de João. Saliente-se que no lugar em que os três núcleos familiares habitam as leis morais são rígidas e a instituição familiar vive sob rigorosos sistemas católico e patriarcal.

${ }^{5}$ O beijo no asfalto foi encenado pela primeira vez em 7 de julho de 1961, no Teatro Ginásio do Rio de Janeiro. O mundo ficcional, neste caso, gira em torno da personagem Arandir, um homem comum que se enquadra num modelo masculino aceitável socialmente: está casado há dois anos com Selminha, trabalha numa firma e é respeitado por todos. Do outro lado, há um desconhecido que perde o equilíbrio na rua, cai e é atropelado por um lotação. Diante da eminência da morte, pede um beijo a Arandir que, generosamente, o dá. A cena é assistida pelo sogro de Arandir, Aprígio, pelos transeuntes e pelo repórter, Amado Ribeiro. 
entre homens como "sodomia", contudo, um crime sem nome; ou ainda, muito tempo depois, especificamente em 1894, quando Lord Alfred Douglas, amigo íntimo e amante de Oscar Wilde, escreveu o poema Two Loves que termina com o famoso verso: "Eu sou o amor que não ousa dizer o nome" ${ }^{\text {, }}$. Ora, não dizer o nome de Arandir, assim como não dizer o amor homoerótico, era o comum, ainda em 1961, quando Nelson Rodrigues escreveu $O$ beijo no asfalto, principalmente, porque causa da vergonha e do preconceito social que a Revolução de 60 ainda não tinha conseguido amenizar.

De forma análoga, no mundo ficcional rodriguiano, pode-se testemunhar atitudes preconceituosas ao homoerotismo por meio da perseguição ao personagem Arandir, abandonado, julgado e condenado socialmente porque a imprensa marrom "criou" seu romance com outro homem. O jogo irônico do dramaturgo sinaliza para a condenação de um inocente, quando, de fato, o inclinado sexualmente se escondia e se colocava ao lado dos acusadores, assumindo um discurso que também o feria em sua orientação sexual. A partir desse motivo, Rodrigues cria uma ironia que desmascara Aprígio diante do leitor/espectador.

Inicialmente, têm-se as falsas pistas, já que aos olhos das filhas, as atitudes do pai - o fato de ter sido contra o casamento, o não-dizer o nome do genro, e a insistência na versão de que Arandir já conhecia o rapaz -, traduzem-se como ciúmes de Selminha. A possibilidade de amor homoerótico, nem de longe, é cogitada, uma vez que Aprígio vive de acordo com o modelo heteronormativo: casou-se, teve filhos e permaneceu ao lado da esposa até a sua morte. Neste caso, os polos opostos: conhecimento e ignorância, inocência e experiência, ocultação e revelação "são completamente dominados por um peculiar objeto de conhecimento: não a sexualidade como um todo, mas especificamente a questão homossexual" (SEDGWICK, 1990, p. 15). Pode-se ver que a família de Aprígio, ao invés de ignorar, não está cônscia de sua condição sexual. Ele, por sua vez, oculta seu desejo, mantendo-se deliberadamente no armário $^{8}$ perante figuras importantes de seu círculo de relações pessoais.

\footnotetext{
${ }^{6}$ Sabe-se que desde o Judaísmo, que "nos deu a tentadora Eva, associando a sexualidade à impureza ou à conspurcação" (BLACKBURN, 2005, p. 75), até o advento do Cristianismo, a sodomia foi condenada, as relações entre homens reprimidas, transformando-se em um crime contra a natureza, caracterizado como "[...] hediondo, mais grave do que o matricídio, a violência sexual contra crianças, o canibalismo, o genocídio e até o deicídio, pecados-crimes mencionáveis, enquanto só o abominável pecado de sodomia foi rotulado e tratado como nefandum" (MOTT, 1994, p. 1).

7 "I am the love that dare not speak its name" (Tradução livre da autora).

${ }^{8}$ Apossamo-nos, aqui, da metáfora forjada por Eve Kosofsky Sedgwick, em Epistemologia do Armário (1990). Segundo Sedgwick, a metáfora do armário é a estrutura que melhor sintetiza a opressão gay no século XX. Para ela, as estruturas mais vastas de ocultação e de revelação, do que é público e do que é privado [...] foram, e são ainda, muito problemáticas relativamente ao género [gender], ao sexo e à economia da cultura heterossexual
} 
Já em O pecado de João Agonia, Santareno faz uso da mesma estrutura opressora, dado que a personagem também se mantém no armário até ir para o serviço militar obrigatório, em Lisboa. Tal qual em $O$ beijo no asfalto, a família de João Agonia ignora sua situação, mas sua irmã, Teresa, percebe que ele retorna dorido e diferente. Sem dúvida, a personagem traz consigo as marcas da experiência vivida na capital portuguesa. Vejamos.

TERESA - E agora... já gostas mais de Lisboa, não é?

JOÃO (Violento) - Não! Tenho raiva a essa terra; raiva de morte. (Fernando, admirado, para de comer: observa João, abanando a cabeça.) TERESA - Não voltas pra lá, pois não?

JOÃO (Feroz) - Nunca mais.

TERESA (A bater palmas.) Seja louvado Nosso Senhor Jesus Cristo! Ainda bem, João, ainda bem!... [...]

JOÃO (Num arrepio.) Mete-me nojo!... Nunca mais hei-de pôr os olhos nessa terra malvada.

RITA (Pressentindo, terna.) - Fizeram-te lá mal, filho?...

JOÃO (Mordendo as palavras.) - Muito mal. (SANTARENO, 1969, p. 33).

Com tanta dor e mágoa entranhadas em suas palavras, ao retornar para casa, o protagonista faz de suas experiências - o envolvimento com um colega de quartel, seu julgamento e sua expulsão do exército - um segredo. É como se João tivesse saído do armário, da opressão dos sentidos, e depois retornado a ela, mantendo-se no silenciamento da própria experiência.

Diante disso, pode-se perceber que tanto o texto de Santareno quanto o de Rodrigues desvelam as vidas de dois homens que negam seus desejos para as pessoas do círculo familiar. Contudo, ao contrário de João, que viveu a experiência homoerótica, Aprígio prefere viver a solidão e o amor platônico por Arandir. Selminha não sabe disso, mas o fato de o pai não ter iniciado um novo relacionamento após a morte de sua mãe, além da perseguição ao seu cônjuge, leva-a a questionar:

SELMINHA - Papai, escuta, papai! (num rompante histérico) Deixa eu falar! (com cruel euforia) O senhor já amou algum dia? Amou alguém?

APRÍGIO - Amei!

SELMINHA (num crescendo de fúria exultante) - Mamãe morreu há tanto tempo e o senhor continua só. Ninguém pode viver sem ninguém. Papai, uma pergunta. [...] Preciso saber se meu pai é capaz de gostar. (suplicante) Neste momento, o senhor gosta de alguém? Ama alguém, papai?

APRÍGIO - Quer mesmo saber?

SELMINHA - Quero.

envolvente. São estruturas dotadas de uma incoerência assaz criativa, embora perigosa, que se vêm, entretanto, condensando de forma contínua e opressiva em certas figurações da homossexualidade (1990, p. 11). 
APRÍGIO (com o olhar perdido) - Querida, neste momento, eu... (esboça uma carícia na cabeça da filha) eu amo alguém (RODRIGUES, 1993, p. 966).

A personagem, mais uma vez, encontra-se numa encruzilhada: de um lado assume que ama alguém, de outro, não pode dizer à filha que a pessoa amada é Arandir. Em outro momento, o dramaturgo cria uma cena que aparenta ser a do desvelamento de Aprígio diante e pela filha Dália, porém, funciona apenas como mostra do jogo rodriguiano em utilizar a ironia como a linguagem do equívoco. Ao procurar por Selminha, Dália diz ao pai que a polícia levou-a para a delegacia. Os dois discutem porque Aprígio chama Arandir de canalha e acusa-o de ser homossexual. Em meio à confusão, Dália age com súbita ferocidade e diz:

DÁLIA - Papai, descobri o seu segredo.

APRÍGIO (realmente em pânico) - Que segredo!?

(Rápido, segura a filha pelo pulso.)

DÁLIA - Descobri!

APRÍGIO (desatinado) - Não tenho segredo nenhum! (com um esgar de choro) Nem admito. Ouviu? Nem admito!

DÁLIA (cruel e lenta) - Quer que eu diga?

APRÍGIO (num berro) - Cala essa boca! (muda de tom. Quase sem voz) Ou, então, diz. Pode dizer. Se você sabe, diz. Qual é o meu segredo?

DÁLIA (lenta e má) - O senhor não gosta de Selminha como pai.

APRÍGIO (assombrado) - Como o quê?

DÁLIA (hirta) - Gosta como. É amor. Amor de homem por mulher.

(Diante da afirmativa de Dália, o velho tem uma reação que, de momento, o espectador não vai compreender. Essa reação é de uma euforia brusca. Total, sem nenhuma motivação aparente.)

APRÍGIO (começando a rir) - Amor de homem por mulher? E é esse o segredo? (repete, recuando para o espanto da filha) Meu segredo é esse?

DÁLIA (esganiçando a voz, num frenético desespero infantil) - Por isso o senhor odeia Arandir!

APRÍGIO (na sua euforia) - Pensei que. (abrindo o riso) Mas quem sabe? Talvez você tenha. (muda de tom, com uma seriedade divertida) Realmente, quando sua filha se casa, o pai é um pouco traído. O sujeito cria a filha para que um miserável venha e. (muda de tom, novamente, com uma ferocidade jocunda) Em certo sentido, Selminha cometeu um adultério contra mim! (numa gargalhada selvagem e canalha, que ninguém entende) Boa! Boa! (RODRIGUES, 1993, p. 979-980).

O diálogo desvela a própria estrutura ideológica que constrói a masculinidade e seu outro, uma vez que Aprígio sente-se aliviado quando a filha revela qual é seu suposto segredo: "amor de homem por mulher". Aprígio ainda se diverte com a inocência de Dália, passando do medo e do pânico de ser descoberto para a canalhice e euforia por permanecer no armário. 
João Agonia, por seu turno, esforça-se para encontrar uma linguagem apta a enunciar a especificidade de seu afeto, e, com a consciência de que não pode negar a si mesmo, justificase diante do amigo, Toino, ao mesmo tempo em que revela seus sentimentos. Observemos.

JOÃO (Desesperado) - Ouve cá, Toino, responde-me com o teu coração nas mãos?: Um homem - o maior, o mais valente! - é capaz de subir lá acima, ao alto da Rocha Grande, e obrigar o vento norte a virar sul? Ou pode chegar ali, à beira do rio, e mandar as águas correrem ao contrário?!... Pode, Toino, diz lá?! Alguém pode fazer com que uma árvore cresca prò fundo da terra, em vez de subir prò ar?!!... Quem, Toino, quem é capaz de fazer isso?!... de subir prò ar?!!... Quem, Toino, quem é capaz de fazer isso?!... (Apanhando, com raiva, o pedaço de madeira) Queres ver, queres? Comecei a talhar aqui a cara de minha mãe... e vês tu o que saiu, vês!...

TOINO - Sou... sou eu, João?!...

JOÃO (Em fúria, arremessando o esboço ao chão) - És, Toino Giesta, és tu!!! (SANTARENO, 1969, p. 147).

A personagem quebra o silêncio, apontando o homoerotismo como uma condição inata e involuntária, e, em seguida, mostra a escultura do rosto de Toino como a prova de que não pode controlar seus desejos, agindo em oposição às ideias de vício, perversão ou contra a natureza, como o seria as águas de um rio correrem na direção contrária. Desse modo, João apresenta o ponto de vista de quem vive a experiência interior homoerótica, indo de encontro à mentalidade cristã da aldeia que via este tipo de prática sexual - "percebida como uma forma extrema do "contra-a-lei" [porque] também infringia decretos tão sagrados como os do casamento, estabelecidos para reger a ordem das coisas e dos seres" (FOUCAULT, 1988, p. 39) - como um dos piores pecados cometidos pelo ser humano.

$\mathrm{Na}$ verdade, em $O$ pecado de João Agonia o homoerotismo aparece em contextos específicos em que as relações de hierarquias e de poder assumem um caráter opressivo. Entretanto, o texto santareniano flagra esse processo não só no ambiente familiar, como também no interior das forças armadas. O dramaturgo, ao propor tirar da penumbra as relações homoeróticas, usa uma faca de dois gumes porque, ao mesmo tempo em que tira João do armário, põe a nu também as relações amorosas entre militares, tópico presente no imaginário literário que, com certeza, satiriza um dos símbolos da virilidade ocidental. Fernando, antes de saber do envolvimento amoroso e sexual do irmão com um colega do exército, é o porta-voz que denuncia a existência desse tipo de relação nos quartéis:

FERNANDO (Enquanto serve o vinho, sempre rindo) - Eh, mas havia lá soldadinho, no meu regimento, que vivia à custa deles: aquilo era cinema, bons fatos...! (Cuspindo no chão, com desprezo). Porcos, gente reles: deviam 
ser todos mortos, todos enforcados!!! (Involuntariamente, empurra a candeia para o lado de João que, assim, fica iluminado de baixo para cima, como que focado) Raça de piolhosos! Lá no teu quartel era o mesmo, não era João?... (João hirto, transido, os lábios trémulos, os olhos muito abertos.) Faço ideia, faço ideia! [...] (SANTARENO, 1969, p. 73).

Mesmo vendo a experiência homoerótica como algo aviltante e vil, pode-se dizer que ao revelar o segredo de João, Manuel Lamas, outro que conviveu com ele no exército, junta-se a Fernando para desnudar também a "transgressão no front" (PITTA, 2003, p. 23). Ele não especifica para a família Agonia o porquê de seu ex-colega ter sido preso, mas quando José inquire sobre o que ocorreu com seu filho em Lisboa, Lamas, antes de tudo, recorre ao jogo irônico, porém, suas palavras comprovam que os atos de João foram julgados pelo exército como crime:

MANUEL - Saber o quê, ti'Zé? Porque é que prenderam o seu filho?... (Em frente de João, fixando-o profundamente, a sorrir, com ódio) Ora, calúnias, as bocas do mundo!... Eu bem sei que eles deram o crime por provado!... Mas isso que tem? Os juízes estão sempre a enganar-se...

RITA (Grito profundo) - Não digas, Manel, vai-te daqui!!!

MANUEL - Crime feio, coisa suja, João Agonia: Deus me livre de ter estado no teu lugar!! Mil vezes um baraço à volta do pescoço... ou o frio que há no fundo dos poços... mil vezes, João!!! Ai, ti'Zé, se vossemecê tivesse ouvido o juiz dizer que... (SANTARENO, 1969, p. 131).

Por certo, ao procurar dar vazão a um homoerotismo flagrante em um ambiente autoritário e considerado viril, Santareno critica a autoimagem da instuiçao e cria polêmica ao ir de encontro à moral, à família e à ordem social. Descortina, assim, o dramaturgo, tantas outras histórias camufladas, negadas e trágicas, uma vez que "[...] esses homens viviam na vergonha do anonimato, no esconderijo dos beijos nunca trocados em público, no silêncio dos prazeres e dores sem uma voz que os enuncie livremente. Silêncio, por sinal, é uma palavrachave em seus mundos" (MELLO, 2008, p. 8) até que alguém ouse não só tirá-los da sombra, num momento opressor guiado pela ditadura salazarista, como também desvelar e desmistificar a imagem austera da masculinidade nas forças armadas.

Analogamente ao que estamos observando em $O$ pecado de João Agonia, em $O$ beijo no asfalto, Nelson Rodrigues promove o desvelamento do homoerotismo ao mesmo tempo em que aponta para a aparência enganosa daqueles que, como Aprígio, não possuíam a coragem de assumir-se diante da família e da sociedade. Há uma luta entre a consciência moral dessa personagem rodriguiana e a força do desejo que o leva a matar Arandir para ser, pelo menos uma vez na vida, verdadeiro e transparente. Observe-se o embate final entre os dois. 


\begin{abstract}
ARANDIR (atônito e quase sem voz) - O senhor me odeia porque. Deseja a própria filha. É paixão. Carne. Tem ciúmes de Selminha.

APRÍGIO (num berro) - De você! (estrangulando a voz) Não de minha filha. Ciúmes de você. Tenho! Sempre. Desde o teu namoro, que eu não digo o teu nome. Jurei a mim mesmo que só diria teu nome a teu cadáver. Quero que você morra sabendo. O meu ódio é amor. Por que beijaste um homem na boca? Mas eu direi o teu nome. Direi teu nome a teu cadáver (RODRIGUES, 1993, p. 988-989). (Grifo meu).
\end{abstract}

Aprígio, enfim, pode dizer o nome de Arandir diante de seu corpo inerte e sem vida. Eis, enfim, o amor que ousa dizer seu nome, mesmo que o desejo homoerótico seja reconhecido e negado a um só tempo.

O fato é que tanto em Rodrigues quanto em Santareno, "a negação da homossexualidade [é] um traço próprio das identidades homossexuais em ambientes adversos" (MIRA, apud BARCELLOS, 2006, p. 42), uma vez que a experiência homoerótica configura-se como índice de aviltamento e de abjeção das personagens e não como uma possibilidade de vida. Talvez, daí também advenha o signo do trágico que os acompanham em suas trajetórias. Se no início, com Tamiris, Apolo, Jacinto, Crisipo e Laio, a tragédia foi a forma encontrada para representar o amor homoerótico; no século XX, o trágico parece, igualmente, ser um recurso literário persistente que dá conta da impossibilidade de realização do amor entre homens, tanto na literatura como na sociedade.

Quanto a este aspecto, Barcellos nos diz que "o mito da tragicidade homossexual é profundamente ambíguo, pois comporta uma dinâmica positiva de afirmação, autopossessão e liberdade, imbricada com os aspectos mais negativos, tais como sofrimento, angústia ou derrota, como, aliás, é próprio do pensamento trágico" (2006, p. 284). Em O pecado de João Agonia, encontramos a persistência desse modelo de representação do homoerotismo, uma vez que João é assassinado para que a ordem prevaleça e a família retorne a seu lugar de honra. Nesse sentido, pode-se verificar a ironia santareniana subjacente a sua representação, dado que ao mesmo tempo que traz o sofrimento e a dor da personagem, o dramaturgo aponta também para a afirmação de sua presença, mesmo que o mundo circundante seja hostil e o negue.

Sob outro ponto de vista, em Nelson Rodrigues, há uma vontade de superar este modelo de representação quando o dramaturgo pretende, antes de tudo, usar o suposto homoerotismo de Arandir para apontar as artimanhas da imprensa marrom e seu poder de forjar histórias, fazer nascer e morrer com a força da palavra. Mas, apesar da força negativa das ações empreendidas pelo jornalista Amado Ribeiro, Arandir é assassinado por Aprígio, que só no 
instante de sua morte pode confessar seu desejo. Por isso, a nosso ver, da mesma forma que há tragicidade na morte de Arandir, há também na trajetória de Aprígio, personagem que mantém uma vida dupla. Importa expor, ainda, que "um dos princípios estruturantes das subjetividades gays e lésbicas consiste em procurar os meios de fugir da injúria e da violência, [e] isso costuma passar pela dissimulação de si mesmo" (ERIBON, 2008, p. 31). O amor de Aprígio por Arandir pode até ter um fim com a morte do genro, porém, sua condição homoerótica não morrerá e continuará circunscrita às forças sociais, afinal, este homem rodriguiano sabe que o mundo circundante não está de braços abertos a seus desejos.

Assim, pode-se perceber que de um lado, Bernardo Santareno aborda a temática dandolhe uma roupagem trágica, e com essa postura, a nosso ver, alude às amarras, à violência e à intransigência do governo salazarista, da Igreja e da sociedade portuguesa que viam a homossexualidade como uma "coisa ruim", um pecado, desvio inaceitável e propulsor do desequilíbrio da ordem coletiva. De outro lado, Nelson Rodrigues trabalha o homoerotismo como a causa da vida dupla, condição da falsa aparência, da exterioridade enganosa que impede Aprígio de se realizar afetiva e sexualmente ao passo que o protege do preconceito.

Neste caso, "a tragédia da condição homossexual é a tragédia do amor que, em determinadas circunstâncias sociais e culturais, não tem possibilidade alguma de ser correspondido" (BARCELLOS, 2006, p. 290-291) e assumido diante de todos. A frase "O meu ódio é amor" dita por Aprígio com a voz estrangulada de choro e dor, antes de atirar em Arandir, no final do terceiro ato, é a grande imagem da ironia cotidiana e social, porque castradora dos desejos e, por consequência, da realização humana, que Rodrigues cria para o chefe de família. Santareno, por sua vez, faz da ironia uma arma de oposição, de denúncia do sufocamento e da castração do indivíduo tanto no nível religioso quanto no social, visto que em Portugal a homossexualidade era entendida como "desvio" à ordem do salazarismo, o que fez com que a maioria dos homossexuais que caíssem nas malhas da polícia fosse internados, espancados e humilhados até 1982, quando ser homossexual deixa oficialmente de ser crime (ALMEIDA, 2009).

\section{Apedrejados por palavras}

Por outro caminho, não menos polêmico, a ironia também se corporifica nas obras rodriguianas e santarenianas por meio da interdiscursividade ao se recuperar outras vozes calcadas na discriminação, que apresentam o homoerotismo e as personagens que o representam como anormais, doentes, "contra-natura" e moralmente incorretos, 
estigmatizando os sujeitos que se afastam dos ideais heteronormativos (COSTA, 1992). Este tipo de linguagem, em Rodrigues e Santareno, é constituído por um discurso híbrido que expõe "vocabulários diversos [que] criam e reproduzem subjetividades diversas", as quais são interpretadas "como idêntica, familiar ou como estranha, exótica e até mesmo desumana [...]" (COSTA, 1992, p. 14). Para tanto, os dramaturgos mesclam elementos de tradiçao religiosa, fragmentos científicos modernos e os rótulos sociais que diferenciam e inferiorizam, ofendem e ferem.

Em O pecado de João Agonia, o protagonista, vítima do preconceito social e familiar, é a primeira personagem que faz uso desse tipo de discurso no momento em que tira o cachecol do pescoço e o joga ao vento: “[...] - Pois tal qual como o vento levou este trapo, assim ele vai levar, de mim pra fora, todas estas lembranças, todas as minhas... sujidades! (Batendo na fronte) Daqui... (no peito) do meu corpo, do meu corpinho todo! [...]" (SANTARENO, 1969, p. 36) (Grifo meu). Sobre o termo "sujidade" utilizado por João, Silvério Trevisan avisa-nos que tanto em Portugal, com a instauração do Santo Ofício, quanto no Brasil colonial, as expressões "sodomia", "pecado nefando" e "sujidade" eram os nomes dados à prática homoerótica (TREVISAN, 2000).

A reinstauração do discurso religioso, oriundo da Summa Theologiae de São Tomás de Aquino, que caracterizava as relações sexuais do casal em termos que incluem a immunditia, ou sujeira, produzirá, em seguida, o tagarelar ruidoso e a quebra da norma, uma vez que no texto de Santareno não há referência ao desperdício do sêmem, mas à crise existencial de João, o enunciador-vítima desse tipo linguagem, sem que, contudo, haja traição do seu significado primeiro: a condenação.

Nesse jogo irônico, João Agonia reproduz uma linguagem "onde o discriminado é forçado a recorrer ao vocabulário do discriminador para identificar-se como sujeito e para reivindicar a consideração moral à qual aspira" (COSTA, 1992, p. 38), encaixando-se temporariamente nos modelos vigentes. A incongruência presente em sua atitude vem para mostrar o quanto a palavra tem poder de articular crenças e ódios, a ponto de fazê-lo odiar e rejeitar o homoerotismo com as palavras daqueles que o espreitam e o apedrejam. É como se ao sentir a primeira palavra no rosto, João se abaixasse para apanhá-la e, em seguida, atirá-la com mais força contra si mesmo.

Mais adiante, o dramaturgo trará o vocabulário oriundo da linguagem de baixo calão interligado ao discurso religioso, o que nos permite ver, de imediato, sua postura irônica ao compor a linguagem da discriminação a partir da confluência enunciativa que qualifica os valores tradicionais dos enunciadores - os homens da família Agonia -, sem deixar, 
entretanto, de desqualificá-los como representantes de uma cultura patriarcal, heteronormativa, religiosa e preconceituosa. Nessa linha, é perceptível que Fernando traz em seu discurso o preconceito por meio do calão, mesmo antes de saber da condição sexual de João, o que, por consequência, mostra-nos que sua atitude diante das relações afetivas entre homens não se deve ao caso do irmão, mas à sua forma de ver tais relações. De sua passagem por Lisboa, quando servia o exército, ele relembra um momento específico:

- [...] Uma vez... foi lá pròs lados de Belém... apareceu-me um, com falinhas doces e mais isto e aquilo... Eh, João, só te digo que lhe dei uma destas cargas... olha, parti-lhe um braço!! (Gargalhada) Havias de vê-lo: a fugir, todo desasado duma banda... e chorava, gania como um cachorro, o tripa-podre! (SANTARENO, 1969, p. 72) (Grifo meu).

Ao trazer o estereótipo "falinhas doces", a personagem contrapõe masculinidade e afeminamento, demonstrando repúdio ao comportamento homossexual. Ligado a isto, vem a violência, o homem dominado pelo puritanismo e pela intolerância que não hesita em punir com agressão a manifestação pública de comportamentos considerados imorais.

Há ódio nas palavras de Fernando, e o adjetivo "podre", com os sentidos de o lado moralmente condenável de alguém, infecto e fétido, aparecerá também na fala de Manuel Lamas: “[...] Eh João Agonia, não vens ajudar o teu (riso de escarninho) o teu amiguinho novo?! (com um rugido, arremessa Toino no chão) Larga-me ranhoso! Já cheiras... cheiras a podre, como ele!...” (SANTARENO, 1969, p. 131) (Grifo meu). A veemência e o ódio que impregnam a linguagem do calão empregada pelas personagens santarenianas estende-se quando a condição homoerótica é tratada como uma doença, a ronha, uma espécie de sarna que pode ser transmitida através do contato com outra pessoa. Na opinião de Lamas, Toino, só por defender o amigo João, já poderia estar "contaminado", indicando-nos que em sociedades tradicionais a amizade com alguém que não é aceito socialmente pode ser considerada um vício ou defeito de caráter.

A alusão ao homoerotismo como uma doença ${ }^{9}$ será, mais uma vez, feita por Fernando quando Carlos, seu tio, avisa aos outros Agonias que, tal qual Manuel Lamas, as pessoas do lugarejo já estavam insinuando que Toino Giesta também era homossexual. O irmão de João,

\footnotetext{
${ }^{9}$ Importa esclarecer que a ciência cria a imagem simbólica do homossexual com um contorno monstruoso, vendo-o como uma espécie anormal. Em consequência, do século XVIII ao XIX, o homoerotismo herda uma espécie de maldição, sendo encarado, ao mesmo tempo, como doença e perversão (FOUCAULT, 1988). No decorrer do século XIX, com a medicalização do homoerotismo, surge o termo "homossexualismo", como marco da dicotomia entre os direcionados eroticamente ao sexo oposto, então considerados "normais", e os chamados "invertidos", que só encontravam o prazer entre os representantes do mesmo sexo, e por isso, qualificados como doentes (POSSAMAI, 2010).
} 
todavia, defende seu cunhado: “- o Toino é são. [...] O ruim, o podre, é o outro... o outro, meu pai, o... João!!! (SANTARENO, 1969, p. 136). Fica claro que Santareno traz uma personagem que divide os homens em heteros, os são, e em homossexuais, os doentes, reinstaurando um discurso científico oriundo do século XIX que associava doença aos homoeroticamente inclinados para dar mostra de como a linguagem literária carrega significados históricos ao mesmo tempo que os denunciam.

Fernando, ainda, usa outros termos: “- Logo ele não ficou preso, lá em Lisboa!... Porque é que este escarro não se enforca? porquê?!!... Quem pode lavar uma nódoa destas?!... Maldita sorte, a minha!!...” (SANTARENO, 1969, p. 136). Enfim, o "tripa-podre”, o "ranhoso", o "podre", o "ruim", o "escarro" e a "nódoa" são metáforas escatológicas, desqualificadoras e inferiorizadoras, com as quais a personagem homoerótica é denominada nos discursos proferidos por aquelas pessoas que o viam como um ser desprezível, abjeto e reles que viera para manchar a honra e a moral da aldeia.

O uso do calão, contudo, vem de mãos dadas com a linguagem religiosa utilizada pelos homens mais velhos da família. Ancorado em um discurso que remete à Idade Média, mas ainda muito usado no contexto em que Santareno produziu seus textos dramáticos, Carlos sentencia que não há pecado mais vergonhoso no mundo do que o de João, obtendo, em seguida, a concordância de José que, angustiado, diz: “- Tenho um filho que pecou: um pecado que é como uma praga de Deus, pior que doença mais ruim, pior que a morte...!! Como é que eu hei-de lavar a sujidade que ele entornou sobre a nossa família?!" (SANTARENO, 1969, p. 137). Pode-se perceber que Santareno recria a prática discursiva que condena o homoerotismo não porque fere o critério de procriação, mas devido à vergonha que causa à família, visto como uma praga que causa malefícios, que prejudica a paz e a harmonia.

No momento em que Miguel diz que João poderia mudar, o pai afirma: “- Não muda, mano Miguel: onde quer que ele esteja, aí estará o seu pecado... Não muda: tem aquele demónio sujo bem entranhado no sangue...!", e segue afirmando que o filho "tem a ira de Deus dentro dele" (SANTARENO, 1969, p. 138), o que nos leva a ver, assim como Jurandir Freire Costa, que o homoerotismo pode ser um fardo muito pesado em sociedades tradicionas, dado que uma vez "etiquetado", o homossexual passará a ser constantemente identificado por sua preferência sexual, condenado moral e religiosamente (COSTA, 1992). O que resta para a personagem, na concepção dos homens da família Agonia, é o inferno religioso da culpa, da vergonha, do castigo divino e da maldição, unindo o pecado com a aberração moral que suja a honra familiar. 
Já em $O$ beijo no asfalto não há muitos termos que desqualifiquem o homoerotismo, uma vez que a oposição se dará a respeito do que é normal ou anormal socialmente. A linguagem, neste caso, surge para diferenciar e discriminar Arandir, em contraposição a uma sociedade que tenta a todo custo manter os homossexuais escondidos de seus olhares. Selminha, depois de toda a campanha jornalística empreendida por Amado Ribeiro, deixará que seu preconceito venha à tona ao considerar as relações sexuais e afetivas entre os homens uma "nojeira", isto é, algo imoral que lhe causa repulsa.

A despeito do nojo sentido pelas relações homoeróticas, além de sua esposa, Arandir terá a sensação de que seu chefe também sentia tal sentimento por ele: “- Até o chefe. Falou comigo, e olhava para mim. Estava espantado. Espantado. Eu tive a impressão. É um bom sujeito. Um homem de bem. Não sei, mas tive a impressão de que tinha nojo de mim, como se eu!” (RODRIGUES, 1993, p. 970). No caso de Selminha, de todos os prismas pelos quais ela poderia analisar o marido, escolhe o físico e o comportamental para convencer a si mesma de que ele, realmente, teve um romance com o rapaz atropelado pelo lotação.

SELMINHA - [...] Como é que um homem pode desejar outro homem. [...] Aliás, Arandir tem certas coisas. Certas delicadezas! E outra que eu nunca disse a ninguém. Não disse por vergonha. (com mais veemência) Mas você sabe que a primeira mulher que Arandir conheceu fui eu. Acho isso Tão! Casou-se tão virgem como eu, Dália! (RODRIGUES, 1993, p. 984).

Mais uma vez, o homoerotismo é desprezado e capaz de suscitar a repugnância das pessoas que fazem parte das relações interpessoais. A fala da esposa de Arandir aponta para o modelo cultural desejável, em algumas camadas sociais e reproduzido pelo senso comum, que tem o heterossexual como um ser insaciável e viril sexualmente que não deve se casar virgem. Arandir se desvia da "normalidade", de acordo com sua esposa, porque tinha certas delicadezas, uma vez que, ao invés de vê-lo como uma pessoa com comportamento meigo e gentil, prefere associar sua brandura à efeminação, ou seja, à estereotipia do homossexual.

Em outro momento, há um embate entre Cunha, o delegado, e Selminha. E, dessa vez, suas vozes serão condutoras de um discurso pautado na questão: o que faz uma pessoa ser ou não ser homem?

CUNHA (com uma satisfação bestial) - Menina, olha. Está na cara que seu marido não é homem. [...]

SELMINHA - [...] (feroz) É homem! (desesperada com a ironia ou incompreensão) Eu conheço muitas [mulheres] que é uma vez por semana, 
duas e, até, quinze em quinze dias. Mas meu marido todo o dia! Todo o dia! Todo o dia! (num berro selvagem) Meu marido é homem! Homem! CUNHA (com um riso sórdido) - Você nunca ouviu falar em gilete? Em barca da Cantareira? (RODRIGUES, 1993, p. 977).

Pode-se perceber que, como fato social, o homoerotismo é particularmente propício à formação de estereótipos, uma vez que sobre ele atuam as mais diversas forças que direcionam a vida em comunidade, entre elas, a moral e a religiosa, como é possível perceber nas obras de Rodrigues e Santareno. Neste sentido, essas construções verbais de ordem sexual buscam sempre igualar, dentro de opiniões correntes indiscriminadas, os mais diversos juízos individuais acerca da homossexualidade (PRETI, 1983). Vê-se, assim, que a provocação de Cunha segue o lugar-comum de que o homem que tem relações afetivas e sexuais com pessoas do mesmo sexo representa a antinorma do ideal de masculinidade, enquanto Selminha defende Arandir usando como argumento a caracterização da masculinidade pela virilidade. Contudo, a réplica do delegado traz os termos "gilete" e "barca da Cantareira"10 para mostrar à mulher de Arandir que ser viril nem sempre é sinônimo de heterossexualidade.

A referência ao tratamento do homoerotismo como uma anomalia, tão comum entre os séculos XIX e XX pelos juristas e médicos, por sua vez, será feita pelo repórter Amado Ribeiro, ao procurar a viúva do atropelado, e ensinar a ela o que dizer para Selminha quando a encontrasse: “- [...] A senhora arranjou, cala a boca. Arranjou um cara quando percebeu, entende? Ao perceber que seu marido mantinha relações anormais com outro homem" (RODRIGUES, 1993, p. 967). Antes de sair do velório, o repórter reforça sua farsa ao assegurar que a relação amorosa, forjada por ele, entre Arandir e a vítima, era "um tipo de intimidade que não podia existir entre homens" (RODRIGUES, 1993, p. 977), donde a tônica é posta, mais uma vez, no entendimento do homossexual como um anormal, conceito oriundo da exaustiva produção do saber sobre o homossexualismo em função do intenso relacionamento entre Direito e a Medicina (GREEN, 2000).

\section{Considerações finais}

\footnotetext{
${ }^{10}$ Faz-se necessário apontar que Nelson Rodrigues tivera de ser convencido pelos atores Fernando Tôrres e Fernanda Montenegro a tornar o texto um pouco mais ofensivo, salpicando-o com alguns palavrões. Castro (1992) avisa-nos que foi a contragosto que o dramaturgo enxertou as duas expressões "gilete" e "barca da Cantareira", que no senso comum referem-se às pessoas que praticavam sexo com homens e mulheres, isto é, os bissexuais.
} 
Em virtude do caminho trilhado para a análise das configurações do homoerotismo, apreendendo e tentando compreender as experiências homoeróticas, em suas especificidades e contexturas próprias nos textos dramáticos santarenianos e rodriguianos, pode-se perceber que apesar de possuírem objetivos diferentes - visto que, a nosso ver, a abordagem de Santareno possui uma clave muito mais política, principalmente por ressignificar o discurso e a moral religiosos, do que a de Rodrigues, que, guardadas todas as proporções, analisa a sociedade brasileira de forma crítica, abordando entre tantos aspectos, os conflitos oriundos da sexualidade masculina, além de fazer uso dos clichês relacionados ao homoerotismo como deboche para desmoralizar, não os gays, mas os detratores de seu teatro -, os dramaturgos conseguem tirar as relações afetivas e sexuais entre homens dos consultórios, confessionários e do âmbito familiar para expô-las literariamente.

Ao trazerem a linguagem que discrimina o homoerotismo para seus textos, Santareno e Rodrigues deixam o leitor desconfortável, pois apontam para o poder das palavras em nomear, com o intuito de excluir tudo o que não se encaixa na ordem vigente, mostrando, assim, que “[...] determinado modo de empregar a linguagem, identifica-se com determinado modo de pensar a sociedade" (ECO, 1971, p. 85). Ou melhor, satirizar para ironizar estas sociedades, uma vez que é pela história das palavras usadas para designar o homoerotismo que se pode iluminar a longa trajetória de perseguições contra os homossexuais e, posteriormente, sua gradual inserção no seio social. Enfim, se o suplício judaico e romano consistia em apedrejar o condenado até que caísse sem vida, nas obras santarenianas e rodriguianas os homossexuais são apedrejados pelas palavras.

Tanto em Santareno quanto em Rodrigues, o homoerotismo é visto como uma transgressão social que não permite a libertação individual das personagens, deixando-lhes como soluções a morte e a solidão. Daí o signo do trágico inerente a João Agonia, Aprígio e Arandir. Outrossim, nas dramaturgias dos dois teatrólogos, os acusadores veem a relação amorosa e sexual entre homens como um pecado, uma perversão ou uma doença, levando-nos a observar que, mesmo no século $\mathrm{XX}$, a criação da personagem homossexual traz, intrinsecamente, uma história e um vocabulário que se reportam a uma inegável realidade preconceituosa. Os dramaturgos, assim, combinam aversão moral com a religiosa.

No caso de $O$ pecado de João Agonia, o discurso religioso é problematizado pela interdiscursividade porque o esquadrinhamento de sua ideologia é construído como o fio condutor do texto. Ao juntar este tipo de linguagem com o discurso da ciência, os homens da aldeia constroem a imagem de João como a representação da maldição, da doença, da perversão, da vergonha, da moléstia contagiosa, pior até do que a lepra. Já Aprígio traz a 
marca dos subterfúgios, tantas vezes necessários em sociedades opressoras, ao não se sentir livre o suficiente para pronunciar o nome de Arandir. Eis o não-dito que diz tanto sobre os homens, podados em seus desejos pelo preconceito ao homoerotismo, que, com certeza, influi sobre seu caráter, excluindo nele até a possibilidade de expressar linguisticamente seu desejo, recusando, por consequência, o reconhecimento social de sua individualidade.

Em uma coisa os dramaturgos convergem: tanto a condição sexual de João quanto o homoerotismo forjado de Arandir transformam-se em motivo de vergonha e rejeição para seus familiares. Além disso, os textos dramáticos de Bernardo Santareno e Nelson Rodrigues dão mostra de que os discursos oriundos da tradição cristã e de meados do século XIX, que vinculavam o homoerotismo a um pecado e a uma patologia, ainda continuavam em circulação, anulando o homossexual e transformando-o em inimigo da ordem social.

\section{Referências bibliográficas:}

ALMEIDA, José. O Estado Novo dizia que não havia homossexuais, mas perseguia-os. Público, Lisboa, 17 jul. 2009. Disponível em: <http://www.publico.pt/Sociedade/o-estadonovo-dizia-que-nao-haviahomossexuais-mas-perseguiaos_1392257?all=1>. Acesso em 29 jul. 2011.

BARCELLOS, José Carlos. Literatura e homoerotismo em questão. Rio de Janeiro: Dialogarts, 2006. Disponível em:< http://www.dialogarts.uerj.br/emquestao/lit_e_homo.pdf $>$. Acesso em 15 jun. 2011.

BARTHES, Roland. Aula. São Paulo: Cultrix, 1989.

BLACKBURN, Simon. Luxúria. São Paulo: Arx, 2005.

BORNHEIM, Gerd. Breves observações sobre o sentido e a evolução do trágico. In: BORNHEIM, Gerd. O sentido e a máscara. São Paulo: Perspectiva, 1975.

BRAIT, Beth. Ironia em perspectiva polifônica. 2. ed. Campinas, SP: Ed. UNICAMP, 2008.

CASTRO, Ruy. O anjo pornográfico: a vida de Nelson Rodrigues. São Paulo: Companhia das Letras, 1992.

COSTA, Jurandir Freire. A inocência e o vício: estudos sobre o homoerotismo. Rio de Janeiro: Relume-Dumará, 1992.

DOUGLAS, Alfred. Two loves. http://law2.umkc.edu/faculty/projects/ftrials/wilde/ poemsofdouglas.htm. Acesso em: $14 \mathrm{dez} .2011$.

ECO, Umberto. A estrutura ausente. São Paulo: Perspectiva, 1971. 
ERIBON, Didier. Reflexões sobre a questão gay. Rio de Janeiro: Companhia de Freud, 2008.

FOUCAULT, Michel. História da sexualidade I: a vontade de saber. 13. ed. Rio de Janeiro: Edições Graal, 1988.

GREEN, James Naylor. Além do carnaval: a homossexualidade masculina no Brasil do século XX. São Paulo: Ed. UNESP, 2000.

HUTCHEON, Linda. Teoria e política da ironia. Belo Horizonte: EdUFMG, 2000.

MELO, Adrián. El amor de los muchachos: homosexualidad \& literatura. Buenos Aires: Ediciones Lea S.A., 2005.

MELlO, Luiz. Aos filhos de Foucault. Cadernos Pagu, n. 30, p. 427-435, jun. 2008. Disponível em:<http://www.scielo.br/pdf/cpa/n30/a23n30.pdf>. Acesso em 14 jul. 2011.

MOTT, Luiz. A etno-história da homossexualidade na América Latina. In: Seminário-Taller de História de la Mentalidad des y los Imaginarios, Colômbia, 22 a 26 de agosto de 1994. Disponível em: <http://www.ufpel.edu.br/ich/ndh/downloads/Luiz_Mott_Volume_04.pdf>. Acesso em 30 ago. 2011.

MUECKE, Douglas Colin. Ironia e o irônico. São Paulo Perspectiva, 1995.

PRETI, Dino. A linguagem proibida: um estudo sobre a linguagem erótica baseado no Dicionário Moderno de Bock, de 1903. São Paulo: T. A. Queiroz, 1983.

PITTA, Eduardo. Fractura: a condição homossexual na literatura portuguesa contemporânea. Coimbra: Angelus Novus, 2003.

POSSAMAI, Paulo César. O homoerotismo na Roma Antiga. Bagoas, Revista de Estudos gays, gêneros e sexualidades. Natal, v. 4, n. 5, p. 79-94, jan./jun. 2010. Disponível em:< http://www.cchla.ufrn.br/bagoas/v04n05art05_possamai.pdf>. Acesso em 4 jun. 2011.

REBELLO, Luiz Francisco. Pósfácio. In: SANTARENO, Bernardo. Obras Completas. 4 vol. Lisboa: Ed. Caminho, 1987, pp. 383-396.

RODRIGUES, Nelson. O beijo no asfalto. In: RODRIGUES, Nelson. Teatro Completo. Rio de Janeiro: Nova Aguilar, 1993, p. 941-990.

SANTARENO, Bernardo. O pecado de João Agonia. Lisboa: Ática, 1969.

SEDGWICK, Eve Kosofsky. Epistemologia do armário. Coimbra: Angelus Novus, 1990.

SZONDI, Peter. Ensaio sobre o trágico. Rio de Janeiro: Jorge Zahar Ed., 2004.

TREVISAN, J. Silvério. Devassos no paraíso: a homossexualidade no Brasil da Colônia à atualidade. Rio de Janeiro: Record, 2000. 
On the paths of irony: homoeroticism in $O$ pecado de João Agonia and $O$ beijo no asfalto

\begin{abstract}
Under the comparative perspective, we aim to analyze the different paths taken by Nelson Rodrigues, Brazilian playwright, and Bernardo Santareno, Portuguese playwright, as to the approach of homoeroticism in $O$ beijo no asfalto and $O$ pecado de João Agonia, respectively. With the goal of dettecting different configurations of the theme and of the discursive language, we intend to check how the irony, in addition to being inserted already in the boldness in addressing the issue, is present in those dramatic texts. Even for bringing this aspect, or exactly for bringing it about, the configurations of male homoeroticism present in the dramatic texts point at the socio-cultural context, to the remnants of prejudice that homoeroticism loads and at the same time, makes individuals deny it.
\end{abstract}

Key words: Bernardo Santareno. Nelson Rodrigues. Irony. Homoeroticism. 